\title{
Primary causes of in-Hospital Mortality in Pediatric Cardiac Surgery Population
}

\author{
TARIQ WAQAR ${ }^{1}$, MUHAMMAD ZUBAIR AHMAD ANSARI ${ }^{2}$ \\ ${ }^{1}$ Associate Prof Pediatric Cardiac Surgery, CPE Institute of Cardiology Multan \\ ${ }^{2}$ Assistant Prof Cardiac Surgery, Cardiac Center Bahawalpur-QAMC \\ Correspondence to: Muhammad Zubair Ahmad Ansari, Email: insar_78@hotmail.com, Cell No.: +923317129899
}

\begin{abstract}
Objective: To present primary causes of in-hospital mortality in large surgical population who underwent surgical correction for CHDs for the period of a decade at our institute.

Methods: Retrospective analysis of pediatric cardiac surgery database along with decision of morbidity and mortality meeting at Department of Cardiac Surgery at CPE Institute of Cardiology from January 2009 to April 2021. Results: An overall 3705 patient underwent surgery for CHDs. The in-hospital mortality for CHDs surgery is $2.37 \%$ with RV dysfunction, Residual cardiac defect with valve dysfunction (TR/PR), pulmonary hypertensive complication, mediastinal bleeding, cardiac tamponade, respiratory complication, MODs, heart block as major primary cause of in-hospital mortality with frequency of $15.91 \%, 18.18 \%, 18.18 \%, 18.18 \%, 9.09 \%, 10.23 \%, 4.54 \%$ and $4.54 \%$ respectively.

Conclusion: in our population of 3705 congenital cardiac surgery patients, incidence of overall in-hospital mortality is promising for wide range of CHDs. RV dysfunction, residual RV defects with vale regurgitation, pulmonary hypertension, bleeding complications and respiratory failure are major primary causes of in-hospital mortality.

Keywords: In-hospital Mortality, Atrial septal defect (ASD), Tetralogy of Fallot (TOF), Ventricular septal defect
\end{abstract}

\section{INTRODUCTION}

Operative mortality is one of the most notable outcome of pediatric and adult cardiac surgery. Mortality fallowing pediatric cardiac surgery is multifactorial that includes type \& complexity of congenital heart defect, intra-operative factor and post-operative ICU complications. ${ }^{1}$ Congenital heart defects (CHD) are mainly divided into cyanotic and acynotic. Atrial septal defect (ASD), Ventircular septal defect (VSD), Patent ductus arteriosus (PDA) etc are most commonly encountered acynotic CHDs while Tetralogy of Fallot (TOF) is most frequently encounter cyanotic CHD in pediatric cardiac surgery practice in Pakistan in addition to many other less frequent CHDs. ${ }^{2,3,4}$ Surgery for more complex CHDs like transposition of great vessels (TGA) is offered at certain specialized pediatric cardiac surgery units across the country. Risk adjustment for congenital heart surgery version 1 (RACHS-1) categorizes the congenital heart disease into six group on the basis of CHDs complexity that ultimately is linked to operative outcome. ${ }^{5}$ Intraoperatively the cross clamp time and total cardiopulmonary bypass time are major determinant of operative outcome along with myocardial protective strategy. Post-operative complication have significant impact over in-hospital mortality. Bleeding, cardiac rhythm problems, respiratory complication, low cardiac output state (LCOS) and infections etc are major known cause of ICU related complication that impact mortality in pediatric population. $6,7,8,9,10$ Hence all above mentioned factor make the entire process of pediatric cardiac surgery as a challenge for the surgical team.

Many of the well developed pediatric cardiac surgery center arrange regular team discussion regarding morbidity and mortality of patient population to improve patient outcome. Our publication is based on the departmental morbidity and mortality meeting (MMM) of congenital cardiac

Received on 25-04-2021

Accepted on 15-06-2021 surgery. The objective of this study is to report the primary causes that leads to in-hospital mortality following congenital cardiac surgery at CPE institute of cardiac surgery over the period of more than a decade. At the same time, this will generate a local statistic based on large pediatric cardiac surgery population. This shall help to guide us to maneuver our team approach to target this primary cause of in-hospital mortality and improve surgical outcome related to congenital cardiac surgery.

\section{MATERIAL AND METHODS}

Approval of study was taken from the ethical committee and institutional review board (IRB). The study is conducted at CPE Institute of Cardiology, Multan. The duration of study spans from January 2009 to April 2021. Cardiac surgery services offered at the institute include both adult and pediatric cardiac surgery. Electronic cardiac surgery database (Cascade Lahore) is used for entry of all patient related information. The study population include all patient who underwent surgery for congenital heart defect (CHDs) while patient who underwent cardiac surgery for non-CHD were excluded.Congenital cardiac surgery was performed by team of cardiac surgery with good expertise in the speciality along with expertise perfusionist team. Institute has developed dedicated congenital cardiac surgery operation suite, intensive care team. For reporting purpose, The patient population is divided into different groups named after surgery for primary pathology like ASD repair, VSD repair, PDA ligation, Repair of TOF, Repair of complete AV canal defect, Resection of right ventricular outflow tract obstruction (RVOTO), Coarctation of aorta repair, repair of partial and total anomalous pulmonary vinous connection (PAPVC \& TAPVC), Pace-maker implantation, Cavo-pulmonary shunt (CP-shunt), BT-shunt etc.

Patient related morbidity and mortality was discussed in MMM once every month. All part of team that include operating surgeon, surgery scrub staff, cardiac perfusionist, 
pediatric anesthetist and intensive care members etc. discuss the pediatric cardiac surgery cases who face major morbidity or mortality. During the meeting different patient related risk factor, disease complexity, intra-operative events, details of cardiopulmonary bypass, course of shifting from operation room to ICU, patient stay in ICU, Lab reports etc are discuss in fine details. The meeting ends with decisions that decide the primary cause of morbidity and mortality.

Primary cause of in-hospital mortality is defined as the first clinical complication that eventually result in clinical demise of patient after congenital hearts surgery. Multiple organ dysfunction syndrome (MODs) and cardiopulmonary failure are not considered as primary cause of death unless no other primary cause is identified.In this study, we reported age (years), gender (male or female), weight $(\mathrm{kg})$, height $(\mathrm{cm})$, Body surface area $(\mathrm{m} 2)$, type of surgery performed as mentioned above, Cardiopulmonary Bypass time (CPB-mins), Ventilation time ((hrs), ICU stay (hrs), inotropes use (hrs), in-hospital mortality and primary cause of mortality. All those informations are retrieved from cardiac surgery electronic database (Cascade Lahore) that generate Microsoft Excel 2007 file and hospital paper record. Numeric variables are reported as mean and standard deviation of mean while categorical variables are reported as frequencies.

\section{RESULTS}

Analysis of data had shown that 3705 case of pediatric cardiac surgery were operated at CPE Institute of cardiology Multan from January 2009 to March 2021. Mean \& standard deviation and frequency for age, gender, weight, height, BSA, CPB time, Cx time, ventilation time, ICU stay, Inotropic support etc are mentioned in table no 1. These statistics revealed that reasonable proportion of congenital heart surgery is performed in grown up kids and young adults. As per protocol of pediatric cardiac surgery and anesthesia, patient age above 3 years or with weight around $10 \mathrm{~kg}$ were entertained for surgical correction of CHDs. Table no.2 showed the overall outcome of pediatric cardiac surgery. Distribution of number of case for ASD repair, VSD repair, TOF repair, PDA lighten, Complete AVcanal defect repair, RVOT resection, Repair of coarctation of Aorta, TAPVC/PAPVC repair, pacemaker implantation, CP-shunt, BT shunt. Table no.2 showed that the overall mortality for all type of pediatric cardiac surgery is $2.37 \%$ $(n=88)$ in 3705 number of congenital heart surgery cases. RV dysfunction, residual cardiac defect with valve regurgitation, pulmonary hypertensive crisis, mediastinal bleeding and cardiac tamponade are prominent primary causes that lead to in-hospital mortality in addition to respiratory complications and MODS as shown in table 2.

When we looked in individual CHD analysis, we found that operative mortality in ASD is $0.91 \%$ with pulmonary hypertensive crisis and RV dysfunction as major primary causes of mortality in addition to mediastinal bleeding, cardiac tamponade and respiratory dysfunction. For VSD and TOF repair, the in-hospital mortality is $2.63 \%$ and $3.91 \%$ respectively with $\mathrm{RV}$ dysfunction, residual defect, mediastinal bleeding and cardiac tamponade are important primary cause of mortality. However pulmonary hypertensive crisis and post-operative complete heart block are also important primary reasons for in-hospital mortality in VSD repair. $0.72 \%$ is operative mortality of PDA lighten surgery and the major primary reason for death is pulmonary hypertensive crisis and intra-operative bleeding in PDA lighten surgery. Surgery for complete AV canal defect carries highest mortality of $7.14 \%$ and the major primary reason for death are $\mathrm{RV}$ dysfunction, residual valve defect and pulmonary hypertensive crisis as shown In table no.2.

\begin{tabular}{|c|c|c|c|c|c|c|c|c|c|c|c|}
\hline $\begin{array}{l}\text { Clinical } \\
\text { infor- } \\
\text { mation }\end{array}$ & $\begin{array}{l}\text { ASD } \\
\text { repair } \\
(n=1203)\end{array}$ & $\begin{array}{l}\text { VSD } \\
\text { Repair } \\
(n=835)\end{array}$ & $\begin{array}{l}\text { TOF } \\
\text { repair } \\
(n=998)\end{array}$ & $\begin{array}{l}\text { PDA } \\
\text { Ligation } \\
(n=413)\end{array}$ & $\begin{array}{l}\text { Com- } \\
\text { plete AV- } \\
\text { Canal } \\
\text { Defect } \\
(n=70)\end{array}$ & $\begin{array}{l}\text { RVOTO } \\
\text { re- } \\
\text { section } \\
(n=63)\end{array}$ & $\begin{array}{l}\text { Repair of } \\
\text { Aortic } \\
\text { coarcta- } \\
\text { tion } \\
(n=38)\end{array}$ & $\begin{array}{l}\text { TAPVC/P } \\
\text { APVC } \\
\text { repair } \\
(n=29)\end{array}$ & $\begin{array}{l}\text { Pacemaker } \\
\text { Implanta- } \\
\text { tion }(n=22)\end{array}$ & $\begin{array}{l}\text { CP-shunt } \\
(n=19)\end{array}$ & $\begin{array}{l}\text { BT-shunt } \\
(n=15)\end{array}$ \\
\hline Age (years) & $\begin{array}{l}24.67+ \\
14.35\end{array}$ & $\begin{array}{l}13.88+ \\
7.51\end{array}$ & $\begin{array}{l}15.87 \\
+7.21\end{array}$ & $\begin{array}{l}14.34+ \\
7.47\end{array}$ & $\begin{array}{l}9.08+ \\
4.62\end{array}$ & $\begin{array}{l}8.62 \\
+3.90\end{array}$ & $\begin{array}{l}20.19+ \\
11.13\end{array}$ & $\begin{array}{l}8.69+ \\
3.77\end{array}$ & $9.18+4.22$ & $\begin{array}{l}8.90+ \\
4.87\end{array}$ & $9.53+4.12$ \\
\hline $\begin{array}{l}\text { Male } \\
\text { Female }\end{array}$ & $\begin{array}{l}39.24 \% \\
60.76 \%\end{array}$ & $\begin{array}{l}57.60 \% \\
42.40 \%\end{array}$ & $\begin{array}{l}61.42 \% \\
38.58 \%\end{array}$ & $\begin{array}{l}57.87 \% \\
42.13 \%\end{array}$ & $\begin{array}{l}31.43 \% \\
68.57 \%\end{array}$ & $\begin{array}{l}37.51 \% \\
63.49 \%\end{array}$ & $\begin{array}{l}63.16 \% \\
36.84 \%\end{array}$ & $\begin{array}{l}31.03 \\
68.97 \%\end{array}$ & $\begin{array}{l}45.45 \% \\
55.55 \%\end{array}$ & $\begin{array}{l}63.16 \% \\
37.84 \%\end{array}$ & $\begin{array}{l}66.67 \% \\
33.33 \%\end{array}$ \\
\hline Weight (kg) & $\begin{array}{l}34.47+ \\
17.87\end{array}$ & $\begin{array}{l}25.49+ \\
18.31\end{array}$ & $\begin{array}{l}26.80+ \\
16.43\end{array}$ & $\begin{array}{l}19.21 \\
+18.36\end{array}$ & $\begin{array}{l}10.52+ \\
10.54\end{array}$ & $\begin{array}{l}17.95+ \\
7.57\end{array}$ & $\begin{array}{l}35.25 \\
+20.35\end{array}$ & $\begin{array}{l}18.80+ \\
5.93\end{array}$ & $19.72+9.04$ & $\begin{array}{l}17.90+ \\
7.54\end{array}$ & $22+13.18$ \\
\hline height (cm) & $\begin{array}{l}140.63+ \\
29.54\end{array}$ & $\begin{array}{l}117.55+ \\
33.61\end{array}$ & $\begin{array}{l}123.53+ \\
31.21\end{array}$ & $\begin{array}{l}103.27+ \\
12.33\end{array}$ & $\begin{array}{l}10.28+ \\
26.85\end{array}$ & $\begin{array}{r}110.43 \\
+24.41\end{array}$ & $\begin{array}{l}126.58+ \\
40.1\end{array}$ & $\begin{array}{l}113.37+ \\
25.76\end{array}$ & $\begin{array}{l}114.41+ \\
27.52\end{array}$ & $\begin{array}{l}110.15+ \\
25.72\end{array}$ & $\begin{array}{l}111.2+ \\
34.43\end{array}$ \\
\hline $\begin{array}{l}\text { BSA } \\
\text { (m2) }\end{array}$ & $\begin{array}{l}1.20+ \\
0.40\end{array}$ & $\begin{array}{l}0.88+ \\
0.36\end{array}$ & $\begin{array}{l}0.98+ \\
0.37\end{array}$ & $\begin{array}{l}0.70+ \\
0.40\end{array}$ & $\begin{array}{l}0.76+ \\
0.30\end{array}$ & $\begin{array}{l}0.73+ \\
0.24\end{array}$ & $\begin{array}{l}1.09+ \\
0.49\end{array}$ & $\begin{array}{l}0.77+ \\
0.20\end{array}$ & $0.78+0.25$ & $\begin{array}{l}0.73+ \\
0.23\end{array}$ & $0.81+0.36$ \\
\hline $\begin{array}{l}\text { CPB time } \\
\text { (mins) }\end{array}$ & $\begin{array}{l}60.44+ \\
21.94\end{array}$ & $\begin{array}{l}76.69+ \\
35.14\end{array}$ & $\begin{array}{l}74.36+ \\
19.22\end{array}$ & NA & $\begin{array}{l}76.7+ \\
12.30\end{array}$ & $\begin{array}{l}76.71+ \\
12.22\end{array}$ & NA & $\begin{array}{l}73.48+ \\
11.33\end{array}$ & N/A & $\mathrm{N} / \mathrm{A}$ & N/A \\
\hline $\begin{array}{l}\text { Ventilation } \\
\text { time (hrs) }\end{array}$ & $\begin{array}{l}5.88+ \\
11.09\end{array}$ & $\begin{array}{l}6.94 \\
+9.87\end{array}$ & $\begin{array}{l}9.95+ \\
35.73\end{array}$ & $\begin{array}{l}2.04+ \\
1.2\end{array}$ & $\begin{array}{l}8.01+ \\
6.59\end{array}$ & $\begin{array}{l}6.22+ \\
1.82\end{array}$ & $\begin{array}{l}6.96+ \\
4.92\end{array}$ & $\begin{array}{l}6.03+ \\
1.57\end{array}$ & $1.54+0.60$ & $\begin{array}{l}7.52+ \\
6.14\end{array}$ & $10+11.31$ \\
\hline $\begin{array}{l}\text { ICU stay } \\
\text { (hrs) }\end{array}$ & $\begin{array}{l}32.80+ \\
24.16\end{array}$ & $\begin{array}{l}37.32+ \\
26.78\end{array}$ & $\begin{array}{l}49.51+ \\
55.42\end{array}$ & $\begin{array}{l}27.17+ \\
19.8\end{array}$ & $\begin{array}{l}36.63+ \\
15.04\end{array}$ & $\begin{array}{l}42.46+ \\
14.80\end{array}$ & $\begin{array}{l}35.51+ \\
32.71\end{array}$ & $\begin{array}{l}39.31+ \\
12.13\end{array}$ & $10.95+3.09$ & $\begin{array}{l}42.94+ \\
11.08\end{array}$ & $\begin{array}{l}24.8+ \\
11.13\end{array}$ \\
\hline $\begin{array}{l}\text { Inotropes } \\
\text { use (hrs) }\end{array}$ & $\begin{array}{l}5.92+ \\
12.06\end{array}$ & $\begin{array}{l}9.22+ \\
18.86\end{array}$ & $\begin{array}{l}26.28+ \\
36.57\end{array}$ & $\begin{array}{l}0.64+ \\
2.07\end{array}$ & $9.2+4.1$ & $\begin{array}{l}10.06+ \\
4.25\end{array}$ & $\begin{array}{l}5.8+ \\
10.86\end{array}$ & $\begin{array}{l}12.37+ \\
3.77\end{array}$ & $0.72+1.15$ & $\begin{array}{l}10.21+ \\
3.93\end{array}$ & $8.93+4.25$ \\
\hline
\end{tabular}




\begin{tabular}{|c|c|c|c|c|c|c|c|c|c|c|c|c|}
\hline $\begin{array}{l}\text { Clinical infor- } \\
\text { mation }\end{array}$ & $\begin{array}{l}\text { ASD } \\
\text { repair } \\
(n=1203)\end{array}$ & $\begin{array}{l}\text { VSD } \\
\text { Re- } \\
\text { pair(n= } \\
835)\end{array}$ & $\begin{array}{l}\text { TOF } \\
\text { repair } \\
(\mathrm{n}=998)\end{array}$ & $\begin{array}{l}\text { PDA } \\
\text { Ligation } \\
(n=413)\end{array}$ & $\begin{array}{l}\text { Com- } \\
\text { plete } \\
\text { AV- } \\
\text { Canal } \\
\text { Defect } \\
(n=70)\end{array}$ & $\begin{array}{l}\text { RVOTO } \\
\text { resection } \\
\text { ( } n=63)\end{array}$ & $\begin{array}{l}\text { Re- } \\
\text { pair } \\
\text { of } \\
\text { Aortic } \\
\text { coarc- } \\
\text { tation } \\
(n=38)\end{array}$ & $\begin{array}{l}\text { TAPVC/ } \\
\text { PAPVC } \\
\text { repair } \\
(n=29)\end{array}$ & $\begin{array}{l}\text { Pace- } \\
\text { maker } \\
\text { Implan- } \\
\text { tation } \\
(\mathrm{n}=22)\end{array}$ & $\begin{array}{l}\text { CP- } \\
\text { shunt } \\
(n=19)\end{array}$ & $\begin{array}{l}\text { BT-shunt } \\
(n=15)\end{array}$ & $\begin{array}{l}\text { Overall } \\
\text { mortality } \\
(n=3705)\end{array}$ \\
\hline $\begin{array}{l}\text { In-hospital } \\
\text { Mortality }\end{array}$ & $\begin{array}{l}0.91 \% \\
(n=11)\end{array}$ & $\begin{array}{l}2.63 \% \\
(n=22)\end{array}$ & $\begin{array}{l}3.91 \% \\
(n=39)\end{array}$ & $\begin{array}{l}0.72 \% \\
(\mathrm{n}=4)\end{array}$ & $\begin{array}{l}7.14 \% \\
(n=5)\end{array}$ & $\begin{array}{l}1.58 \% \\
(n=1)\end{array}$ & $\begin{array}{l}5.2 \% \\
(n=2)\end{array}$ & $\begin{array}{l}3.45 \% \\
(n=1)\end{array}$ & $0 \%$ & $\begin{array}{l}10.52 \% \\
(n=2)\end{array}$ & $\begin{array}{l}6.67 \% \\
(n=1)\end{array}$ & $\begin{array}{l}2.37 \% \\
(n=88)\end{array}$ \\
\hline RV dysfunction & $\begin{array}{l}18.18 \% \\
(n=2)\end{array}$ & $\begin{array}{l}9.09 \% \\
(n=2)\end{array}$ & $\begin{array}{l}23.08 \\
\% \\
(n=9)\end{array}$ & $0 \%$ & $\begin{array}{l}20 \% \\
(n=1)\end{array}$ & $0 \%$ & $0 \%$ & $0 \%$ & $0 \%$ & $0 \%$ & $0 \%$ & $\begin{array}{l}15.91 \% \\
(n=14)\end{array}$ \\
\hline $\begin{array}{l}\text { Residual defect } \\
\text { with TR/PR }\end{array}$ & $0 \%$ & $\begin{array}{l}22.72 \% \\
(n=5)\end{array}$ & $\begin{array}{l}25.64 \\
\% \\
(n=10)\end{array}$ & $0 \%$ & $\begin{array}{l}20 \% \\
(n=1)\end{array}$ & $0 \%$ & $0 \%$ & $0 \%$ & $0 \%$ & $0 \%$ & $0 \%$ & $\begin{array}{l}18.18 \% \\
(n=16)\end{array}$ \\
\hline $\begin{array}{l}\text { Pulmonary } \\
\text { Hypertensive } \\
\text { crisis }\end{array}$ & $\begin{array}{l}54.54 \% \\
(n=6)\end{array}$ & $\begin{array}{l}13.63 \% \\
(n=3)\end{array}$ & $0 \%$ & $\begin{array}{l}75 \% \\
(\mathrm{n}=4)\end{array}$ & $\begin{array}{l}60 \% \\
(n=3)\end{array}$ & $0 \%$ & $0 \%$ & $0 \%$ & $0 \%$ & $0 \%$ & $0 \%$ & $\begin{array}{l}18.18 \% \\
(n=16)\end{array}$ \\
\hline Bleeding & $\begin{array}{l}9.09 \% \\
(n=1)\end{array}$ & $\begin{array}{l}13.63 \% \\
(n=3)\end{array}$ & $\begin{array}{l}20.51 \\
\% \\
(n=8)\end{array}$ & $\begin{array}{l}25 \% \\
(n=1)\end{array}$ & $0 \%$ & $0 \%$ & $\begin{array}{l}100 \% \\
(n=2)\end{array}$ & $0 \%$ & $0 \%$ & $\begin{array}{l}50 \% \\
(n=1)\end{array}$ & $\begin{array}{l}100 \% \\
(n=1)\end{array}$ & $\begin{array}{l}18.18 \% \\
(n=16)\end{array}$ \\
\hline $\begin{array}{l}\text { Cardiac Tam- } \\
\text { ponafe }\end{array}$ & $\begin{array}{l}9.09 \% \\
(n=1)\end{array}$ & $\begin{array}{l}9.09 \% \\
(n=2)\end{array}$ & $\begin{array}{l}12.82 \\
\% \\
(n=5)\end{array}$ & $0 \%$ & $0 \%$ & $0 \%$ & $0 \%$ & $0 \%$ & $0 \%$ & $0 \%$ & $0 \%$ & $\begin{array}{l}9.09 \% \\
(n=8)\end{array}$ \\
\hline $\begin{array}{l}\text { Respiratory } \\
\text { distress syn- } \\
\text { drom }\end{array}$ & $\begin{array}{l}9.09 \% \\
(n=1)\end{array}$ & $\begin{array}{l}13.63 \% \\
(n=3)\end{array}$ & $\begin{array}{l}12.82 \\
\% \\
(n=5)\end{array}$ & $0 \%$ & $0 \%$ & $0 \%$ & $0 \%$ & $0 \%$ & $0 \%$ & $0 \%$ & $0 \%$ & $\begin{array}{l}10.23 \% \\
(n=9)\end{array}$ \\
\hline MODS & $0 \%$ & $0 \%$ & $\begin{array}{l}5.13 \% \\
(n=2)\end{array}$ & $0 \%$ & $0 \%$ & $0 \%$ & $0 \%$ & $\begin{array}{l}100 \% \\
(n=1)\end{array}$ & $0 \%$ & $\begin{array}{l}50 \%(n- \\
1)\end{array}$ & $0 \%$ & $\begin{array}{l}4.54 \% \\
(n=4)\end{array}$ \\
\hline Sepsis & $0 \%$ & $0 \%$ & $0 \%$ & $0 \%$ & $0 \%$ & $100 \%$ & $0 \%$ & $0 \%$ & $0 \%$ & $0 \%$ & $0 \%$ & $0 \%$ \\
\hline Stroke/coma & $0 \%$ & $0 \%$ & $0 \%$ & $0 \%$ & $0 \%$ & $0 \%$ & $0 \%$ & $0 \%$ & $0 \%$ & $0 \%$ & $0 \%$ & $0 \%$ \\
\hline Heart Block & $0 \%$ & $\begin{array}{l}18.18 \% \\
(n=4)\end{array}$ & $0 \%$ & $0 \%$ & $0 \%$ & $0 \%$ & $0 \%$ & $0 \%$ & $0 \%$ & $0 \%$ & $0 \%$ & $\begin{array}{l}4.54 \% \\
(n=4)\end{array}$ \\
\hline $\begin{array}{l}\text { VF/cardiac } \\
\text { rhythm }\end{array}$ & $0 \%$ & $0 \%$ & $0 \%$ & $0 \%$ & $0 \%$ & $0 \%$ & $0 \%$ & $0 \%$ & $0 \%$ & $0 \%$ & $0 \%$ & $0 \%$ \\
\hline
\end{tabular}

RVOTO resection and pacemaker implantation carries negligible in-hospital mortality. Repair of TAPVC/PAPVC had $3.45 \%$ mortality and MODS is the reason of in-hospital mortality. Repair of Coarctation of aorta, CP-shunt and BT shunt had operated mortality of $5.2 \%, 10.52 \%$ and $6.67 \%$ respectively. Intra-operative and post-operative bleeding and MODs are major primary cause that lead to death. All above mentioned informations are summarized in table 2 .

\section{DISCUSSION}

Surgical repair for CHDs is challenging particularly in our part of the world because of certain loco-regional factors. The one is high incidence of CHDs and late diagnosis of disease due to non-availability of expertise because of less well-established healthcare system ${ }^{11}$. Majority of complex CHDs patient present very late. Sequela of late presentation is advancement in disease pathophysiology when operative risk for surgical treatment is substantially high or pathology become inoperable (Eisenmenger syndrome) ${ }^{12}$. Over the period of last decade, services of congenital cardiac surgery had grown substantially across the country. Our surgical results are based on large population who underwent congenital heart surgery for various simple and complex CHDs. Our operative results are promising and matches the international statistics despite our surgical populations was complex due to late presentation and poor socioeconomic/educational background.

CHDs with left to right shunt without restriction to pulmonary flow like ASD, VSD, complete AV-canal defect and PDA showed element of pulmonary hypertension as pathophysiology of disease. The severity of pulmonary hypertension depends on amount and duration of shunted blood along with response pulmonary arterial tree ${ }^{13} . \mathrm{Qp}$ \& Qs ratio help to identify patient who are operable or noneoperable along with non-invasive echocardiographic findings ${ }^{14}$. However there is reasonable number of patient groups who have borderline pulmonary hypertension (operable but high pulmonary hypertension). Cardiopulmonary bypass and entire surgical process yield number of chemical substances in the body that make manipulation of pulmonary hypertensive response challenging ${ }^{15}$. At the same time it lead to RV dysfunction as well ${ }^{16}$. So in above mentioned CHDs of our population, pulmonary hypertension and and RV dysfunction with or without valve regurgitation are major primary cause that lead to in-hospital mor- 
tality. In CHDs like TOF, raise hematocrit and platelet dysfunction make hemostatic process challenging during course of surgery and early ICU stay ${ }^{17}$. At the same time complexity of disease and presence of RV dysfunction and valve regurgitation like TR or PR after surgery make overall patient management a big challenge. Thus RV dysfunction along with TR or PR, residual VSD with overdid risk of bleeding complication (mediastinal bleed and cardiac tamponade) are significant cause of in-hospital mortality. Resection of RVOTO carries low mortality as it lack of pulmonary vasculature reactivity. Repair of coarctation of aorta, CP-shunt and BT-shunt are usually closed heart procedure or procedure where CPB is not used. These are technically challenging due to surgical exposure and disease presentation itself. Meticulous stitching and creation of good geometric anastomosis is pivotal to success in these procedure. Bleeding from these anastomotic site and failure of surgically created shunt are major concerns and primary cause of death ${ }^{18}$. Procedure like epicardial implantation of Pacemaker carries very low mortality and rewarding unless some iatrogenic injury happen.

Surgery for CHDs carries good overall outcome if a good expertise facility is available. RV dysfunction, residual shunt with valve dysfunction, pulmonary hypertensive pathology, bleeding/cardiac tamponade etc are major primary cause of in-hospital mortality. Focused approach for proper disease work-up particularly related pulmonary vasculature and RV function, meticulous surgical technique, Intensive care team work/ response and provision of good pharmacological support can yield even more impressive outcome for congenital hearts surgery.

\section{CONCLUSION}

In our population of 3705 pediatric cardiac surgery patient, incidence of overall in-hospital mortality is promising for wide range of CHDs. RV dysfunction, residual $\mathrm{RV}$ defects with vale regurgitation, pulmonary hypertension, bleeding complications and respiratory failure are major primary causes of in-hospital mortality.

\section{REFERENCES}

1. Martin GR, Jonas RA. Surgery for Congenital Heart Disease: Improvements in Outcomes. Am J Perinatol. 2018 May;35(6):557-560. doi: 10.1055/s-0038-1639358. Epub 2018 Apr 25. PMID: 29694996.

2. Farooqui R, Haroon UF, Niazi a, Rehan N, Butt TK, Niazi M. Congenital heart diseases in neonates. J Rawal Med Coll. 2010;14:31-32.

3. Chaudhry TA, Younas M, Baig A. Ventricular septal defect and associated complications. J Pak Med Assoc. 2011 Oct;61(10):1001-4. PMID: 22356036.

4. Bakhtyar Zahid S, Zeb Jan A, Ahmed S, Achakzai H. Spectrum of congenital heart disease in children admitted for cardiac surgery at Rehman Medical Institute, Peshawar, Pakistan. Pak J Med Sci. 2013 Jan;29(1):173-6. doi: 10.12669/pjms.291.2910. PMID: 24353534; PMCID: PMC3809184.

5. Nina RV, Gama ME, Santos AM, Nina VJ, Figueiredo Neto JA, Mendes VG, Lamy ZC, Brito LM. Is the RACHS-1 (risk adjustment in congenital heart surgery) a useful tool in our scenario? Rev Bras Cir Cardiovasc. 2007 OctDec;22(4):425-31. English, Portuguese. doi: 10.1590/s010276382007000400008. PMID: 18488109.
6. Larsen SH, Emmertsen K, Johnsen SP, Pedersen J, Hjortholm K, Hjortdal VE. Survival and morbidity following congenital heart surgery in a population-based cohort of children--up to 12 years of follow-up. Congenit Heart Dis. 2011 Jul-Aug;6(4):322-9. doi: 10.1111/j.1747-0803.2011.00495.x. Epub 2011 Mar 21. PMID: 21418533.

7. Crowe S, Brown KL, Pagel C, Muthialu N, Cunningham D, Gibbs J, Bull C, Franklin R, Utley M, Tsang VT. Development of a diagnosis- and procedure-based risk model for 30day outcome after pediatric cardiac surgery. J Thorac Cardiovasc Surg. 2013 May;145(5):1270-8. doi: 10.1016/j.jtcvs.2012.06.023. Epub 2012 Jul 18. PMID: 22818122.

8. Epting CL, McBride ME, Wald EL, Costello JM. Pathophysiology of Post-Operative Low Cardiac Output Syndrome. Curr Vasc Pharmacol. 2016;14(1):14-23. doi: 10.2174/1570161113666151014123718. PMID: 26463989.

9. Agarwal HS, Wolfram KB, Saville BR, Donahue BS, Bichell DP. Postoperative complications and association with outcomes in pediatric cardiac surgery. J Thorac Cardiovasc Surg. 2014 Aug;148(2):609-16.e1. doi: 10.1016/j.jtcvs.2013.10.031. Epub 2013 Nov 23. PMID: 24280709.

10. Wolf MJ, Maher KO, Kanter KR, Kogon BE, Guzzetta NA, Mahle WT. Early postoperative bleeding is independently associated with increased surgical mortality in infants after cardiopulmonary bypass. J Thorac Cardiovasc Surg. 2014 Aug;148(2):631-6.e1. doi: 10.1016/j.jtcvs.2013.10.050. Epub 2013 Dec 9. PMID: 24332187.

11. Richardson CJ, Itua $P$, Duong $T$, Lewars J, Tiesenga $F$. Racial and socioeconomic disparities in congenital heart surgery: A research article. J Card Surg. 2021 Jul;36(7):2454-2457. doi: 10.1111/jocs.15511. Epub 2021 Mar 22. PMID: 33749883.

12. Agha MM, Glazier RH, Moineddin R, Moore AM, Guttmann A. Socioeconomic status and prevalence of congenital heart defects: does universal access to health care system eliminate the gap? Birth Defects Res A Clin Mol Teratol. 2011 Dec;91(12):1011-8. doi: 10.1002/bdra.22857. Epub 2011 Oct 17. PMID: 22002854.

13. Alakhfash AA, Alqwaiee A, Alakhfash GA, Alhajjaj A, Almesned AA. Pulmonary hypertension associated with congenital heart disease; clinical decision scenario. Respir Med Case Rep. 2020 Nov 11;31:101286. doi: 10.1016/j.rmcr.2020.101286. PMID: 33294357; PMCID: PMC7683341.

14. Gokalp S, Guler Eroglu A, Saltik L, Koca B. Relationships between left heart chamber dilatation on echocardiography and left-to-right ventricle shunting quantified by cardiac catheterization in children with ventricular septal defects. Pediatr Cardiol. 2014 Apr;35(4):691-8. doi: 10.1007/s00246-0130839-5. Epub 2013 Nov 21. PMID: 24259011.

15. Schulze-Neick I, Li J, Penny DJ, Redington AN. Pulmonary vascular resistance after cardiopulmonary bypass in infants: effect on postoperative recovery. J Thorac Cardiovasc Surg. 2001 Jun;121(6):1033-9. doi: 10.1067/mtc.2001.113747. PMID: 11385367.

16. Cassady SJ, Ramani GV. Right Heart Failure in Pulmonary Hypertension. Cardiol Clin. 2020 May;38(2):243-255. doi: 10.1016/j.ccl.2020.02.001. PMID: 32284101.

17. Wise-Faberowski L, Irvin M, Quinonez ZA, Long J, Asija R, Margetson TD, Hanley FL, McElhinney DB. Transfusion Outcomes in Patients Undergoing Unifocalization and Repair of Tetralogy of Fallot With Major Aortopulmonary Collaterals. World J Pediatr Congenit Heart Surg. 2020 Mar;11(2):159165. doi: 10.1177/2150135119892192. PMID: 32093560.

18. Gérelli S, Boulitrop C, Van Steenberghe M, Maldonado D, Bojan M, Raisky O, Sidi D, Vouhé PR. Bidirectional cavopulmonary shunt with additional pulmonary blood flow: a failed or successful strategy? Eur J Cardiothorac Surg. 2012 Sep;42(3):513-9. doi: 10.1093/ejcts/ezs053. Epub 2012 Feb 24. PMID: 2236819 